\title{
Alternatives for the Treatment of Giant Cell Tumor in the Peripheral Tumor Service of the CCOI Frank País
}

\author{
Alicia Tamayo Figueroa*1, Carlos González de Varona ${ }^{2}$, Ragnar Calzado Calderón ${ }^{1}$, José E Pérez \\ González ${ }^{3}$, Vilma Rondón García ${ }^{4}$ and Juan Carlos Álvarez Rodríguez ${ }^{5}$ \\ ${ }^{1}$ Especialista de 2 do grado en Ortopedia y Traumatología, Cuba \\ ${ }^{2}$ Especialista de 1 er grado MGI y 1 er grado en Ortopedia y Traumatología. Profesor asistente, Cuba \\ ${ }^{3}$ Especialista 1er grado Ortopedia y Traumatología, Cuba \\ ${ }^{4}$ Especialista 2 do grado Radiología, Cuba \\ ${ }^{5}$ Licenciado en Defectología. Profesor asistente, Cuba \\ *Corresponding author: Alicia Tamayo Figueroa, Complejo Científico Ortopédico Internacional "Frank País", Ave 51, \# \\ 19603, e/ 196 y 202, La Lisa, La Habana, Cuba
}

\begin{tabular}{|c|c|}
\hline ARTICLE INFO & ABSTRACT \\
\hline Received: 些 January 08, 2021 & $\begin{array}{l}\text { Citation: Alicia Tamayo Figueroa, Carlos González de Varona, Ragnar Calzado Calderón, } \\
\text { José E Pérez González, Vilma Rondón García, Juan Carlos Álvarez Rodríguez. Alternatives }\end{array}$ \\
\hline Published: January 19, 2021 & $\begin{array}{l}\text { for the Treatment of Giant Cell Tumor in the Peripheral Tumor Service of the CCOI Frank } \\
\text { País. Biomed J Sci \& Tech Res 33(2)-2021. BJSTR. MS.ID.005368. }\end{array}$ \\
\hline
\end{tabular}

\section{Mini Review}

GCT is a rare aggressive tumor ( $9 \%$ of all bone tumors) considered to be of low grade of malignancy that requires a good relationship between clinical, radiological and histopathological diagnosis due to the fact that there are numerous diseases with giant cells of which it is necessary to perform a good differential diagnosis to avoid diagnostic errors [1-4]. The lesion is solitary and becomes symptomatic when it has destroyed enough bone tissue. In this paper, we present a casuistry of 122 cases treated at the Frank País International Orthopedic Scientific Complex, in the tumor service between 2000 and 2018, with the aim of correlating them with the treatments described in the literature [5-7].

\section{Alternatives for Treatment}

The treatment of GCT is controversial and controversial and includes various options such as:

1) Curettage and graft of autologous or homologous bone.

2) Curettage and polymethylmethacrylate (PMMA) insert

3) Cryotherapy after curettage.
4) Curetting and washing of the cavity with phenol, alcohol, Zinc chloride and hydrogen peroxide, milling of the cavity and insertion of PMMA or bone graft.

5) En bloc resection and bone transport with external fixator or tumor prosthesis.

6) Radiation therapy

7) Embolization of the vessels that feed it.

We usually use curettage, washing of the cavity with hydrogen peroxide and insertion of PMMA, which controls recurrences between 80 and $90 \%$ of cases with much better results than bone graft insertion and also facilitates early ambulation, rehabilitation. immediate and social incorporation of the patient in a shorter period of time [8-15]. We have used amputation in those cases of malignant GCT with soft tissue infiltration or those located in short bones that have not been feasible for another surgery and due to the high risk of metastasizing (Figures 1-7). 


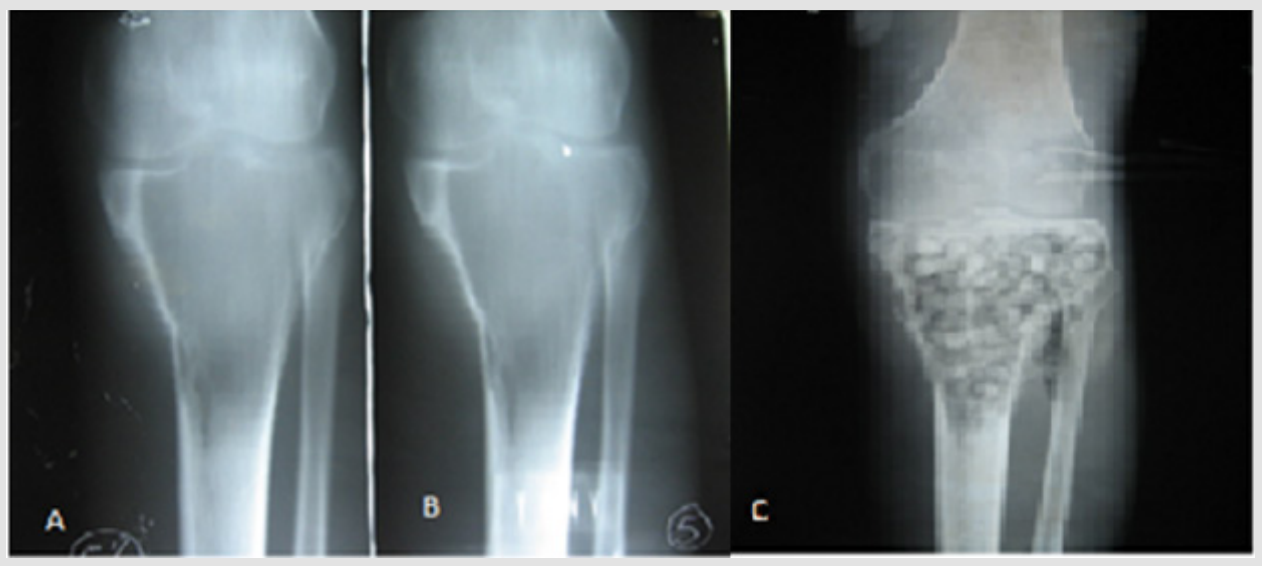

Figure 1:

A. A and B shows the osteolytic epiphysometaphyseal lesion with thinning of the cortices.

B. C Image showing the filling of the lesion with cancellous bone after curettage in the proximal 1/3 of the tibia.

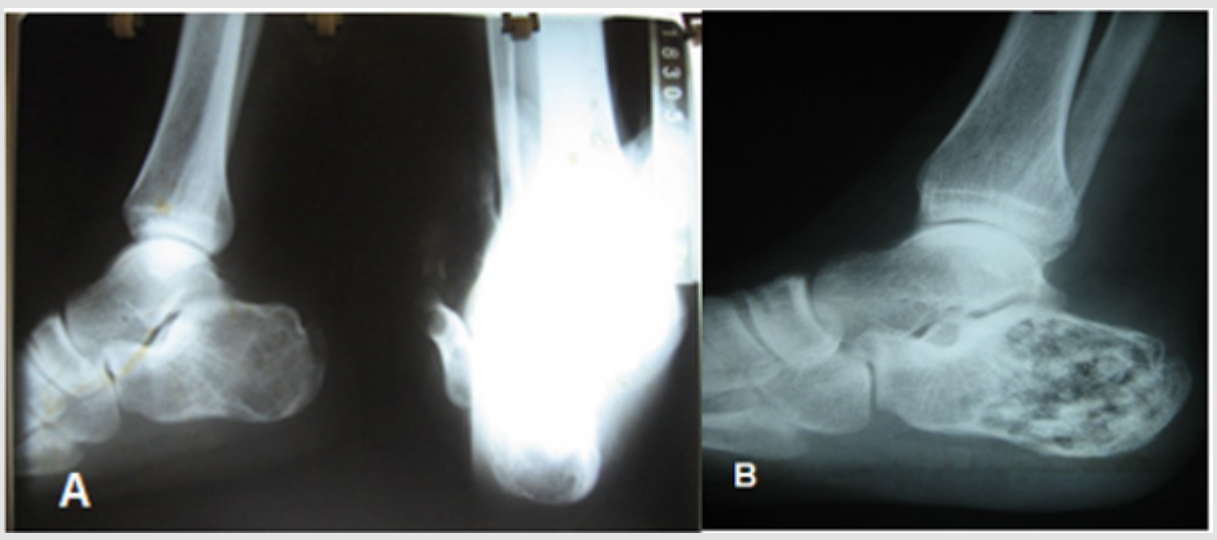

Figure 2:

A. Lesion at the calcaneus level showing osteolysis.

B. Filling of the lesion after curettage with incorporation of the bone graft.

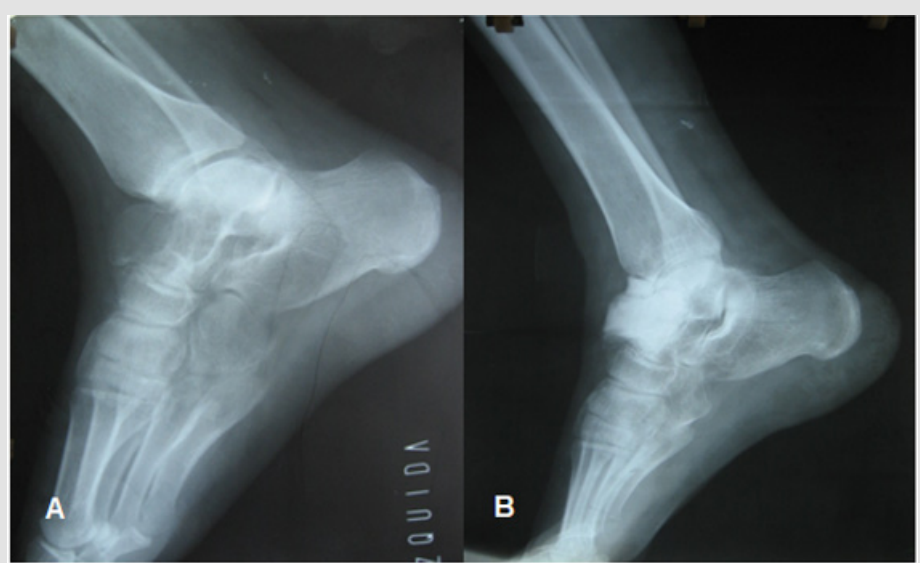

Figure 3:

A. Osteolytic lesion at the level of the talus.

B. filling the lesion with cement (PMMA) and immediate rehabilitation of the patient. 


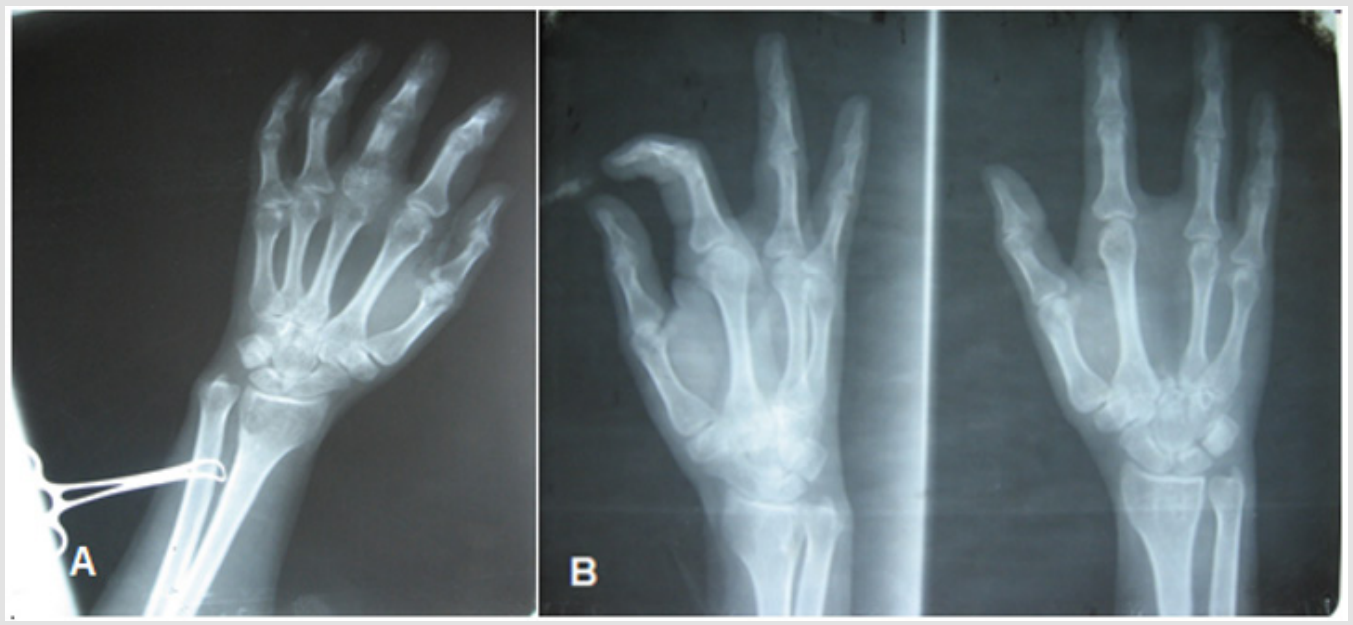

Figure 4: Giant cell tumor located at the level of the proximal epiphysis of the first phalanx of the 3rd finger. B Beam amputation for diagnosis of malignancy.

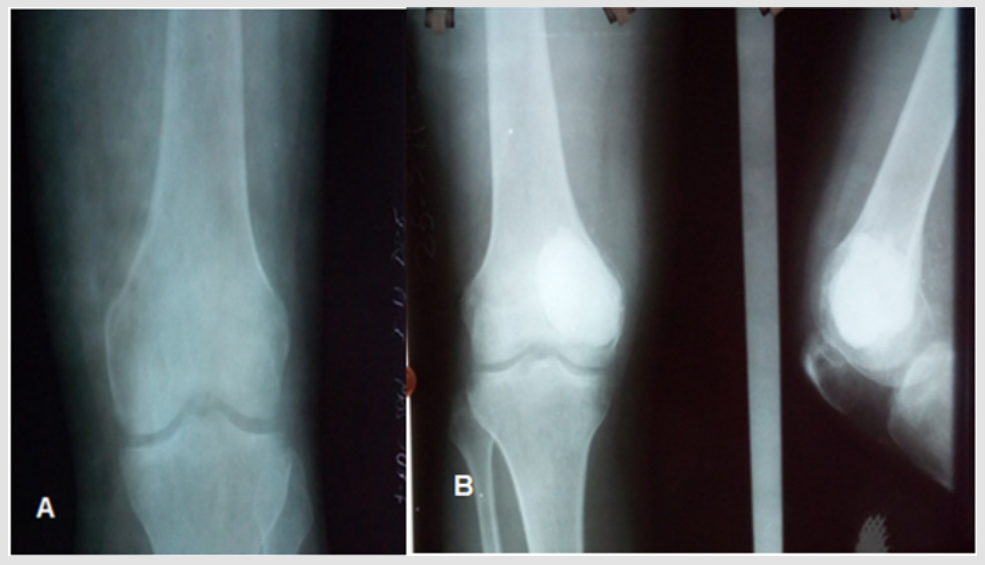

\section{Figure 5:}

A. Distal epiphyseal lesion of the femur compatible with diagnosis of GCT.

B. Filling of the lesion with cement (PMMA

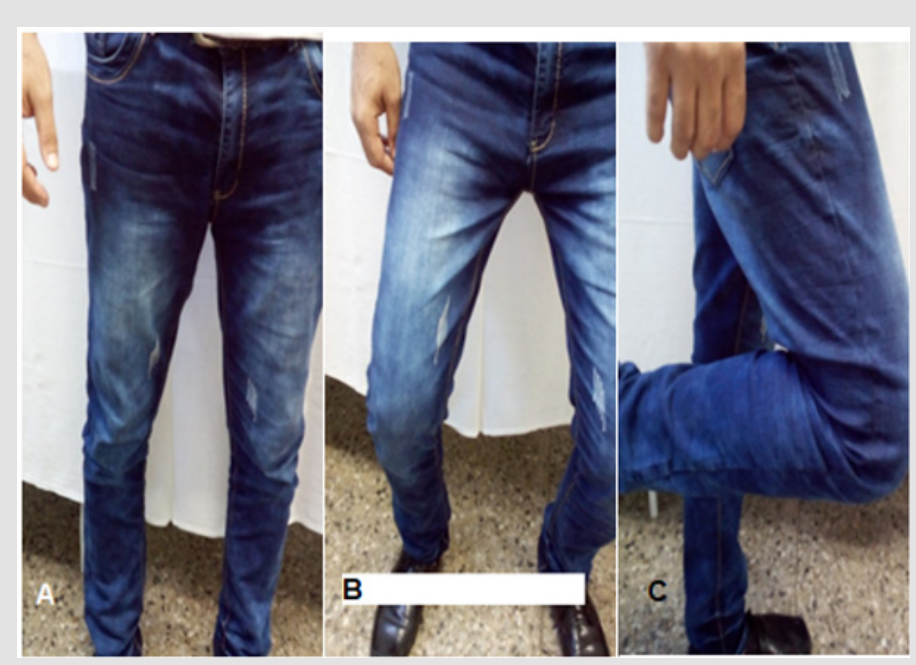

Figure 6: Same previous case where the functionality of the filling with PMMA is shown. A weight bearing support B and C bending. 


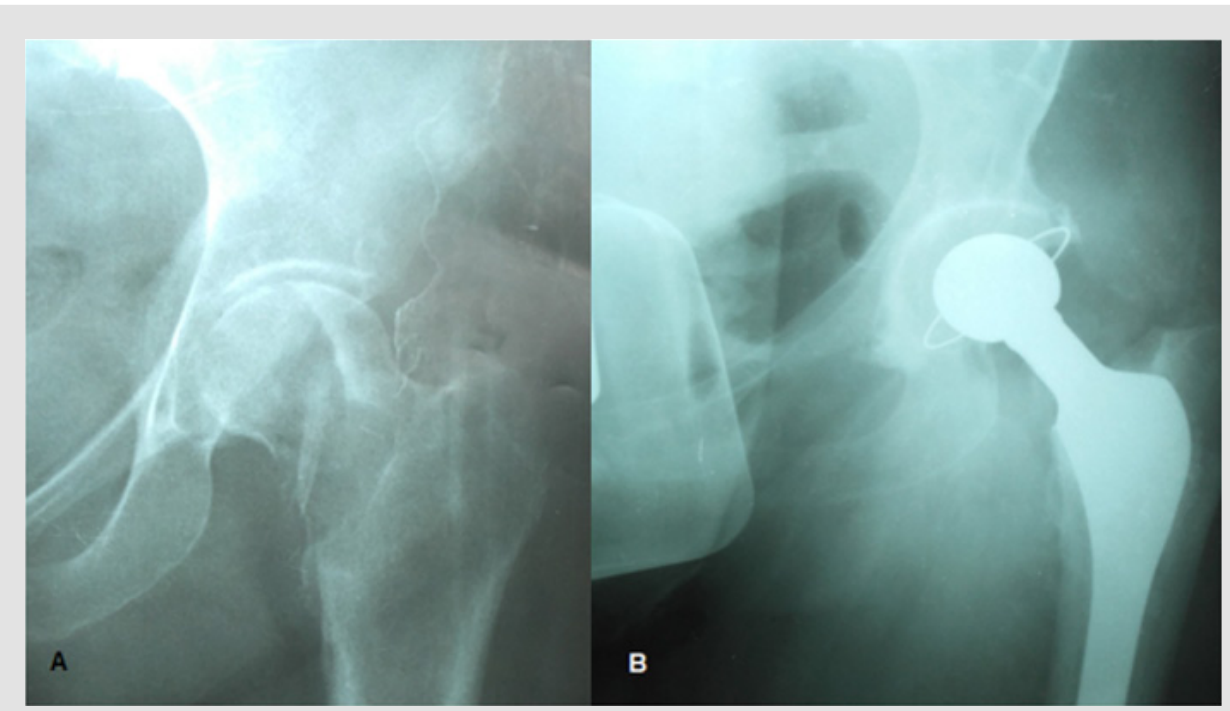

\section{Figure 7:}

A. Giant Cell Tumor at the epiphyseal level of the left hip.

B. Total prosthetic hip replacement.

\section{Discussion}

GCT represents around 5\% of all primary bone tumors (4 to $10 \%$ ) The presence of giant cells is common in some benign tumors, but GCT is considered to be one in which only these cells are found without a specific stroma [16-20]. It has been known since the $19^{\text {th }}$ century, described by Aslley and Cooper in 1818 and redefined by Jaffe et al. In 1940. It was defined as an "aggressive tumor", characterized by the presence of highly vascularized tissue with spindle or ovoid cells and multiple multinucleated giant cells or osteoclasts, may have frequent recurrences and a limited ability to metatize ( 5 to $10 \%$ of cases). It mostly affects women between 20 and 40 years of age after epiphyseal closure or mature skeleton. It is most frequently located around the knee (50\%). In the epiphyses or articular ends (distal to the femur and proximal to the tibia), it is followed in frequency by the distal radius and the proximal humerus [21-24]. It rarely appears in the spine and skull. In a very low percentage $(1 \%)$ multiple lesions can appear and in this case affect the short bones of the hands and feet. When they appear metaphyseal, they are infrequent and appear in patients who have not reached skeletal maturity. There is a radiological classification established by Enneking that divides them into three stages:

Stage 1: It is a latent and benign GCT with slow growth, only locally aggressive.

Stage 2: GCT has well-defined margins with the cortical only thinned or insufflated.

Stage 3: It is aggressive with rapid growth with pathological fracture, destruction of the medullary and cortical bone with its rupture and invasion of soft tissues.

This classification has prognostic value since it is in stage 3 where metastases appear.
Currently the TCG, according to its biological behavior, is classified as:
a. Benign.
b. Evil one.

\section{Conclusion}

The Giant Cell Tumor is more frequent in females between 20 and 40 years old, it is located mainly in the distal epiphysis of the femur, proximal of the tibia and distal of the radius. The management of these patients was mostly by curettage and filling with PMMA. Amputation is reserved for cases that present soft tissue infiltration.

The functional evolution in most of the cases in which an adequate diagnosis and treatment is carried out is good, presenting recurrences less frequently.

\section{Conflict of Interests}

The authors of this work certify that there are no conflicts of interest in the performance of this work.

\section{References}

1. Jaffe HL, Lichtenstein, Portis RB (1940) Giant Cell Tumor of bone. Arch Pathol 30: 993-1031.

2. Schajowicz F (1982) Tumores y lesiones óseas pseudotumorales de huesos y articulaciones. Ed. Panamericana. Buenos Aires.

3. Obregón Gaitán D, Delgado Martínez AD (2007) Tumores primitivos del hueso. Curso de actualización ortopédica y traumatológica. Tema p. 25.

4. Enneking WF (1983) Musculoskeletal tumor surgery. Churchill Livingstone, New York, USA, pp. 87-88.

5. Luis Daniel Valladares-Vijil, Héctor Silva-Cárcamo, Roger ArmandoDominguez (2015) Giant Cell Tumor of Bone: Incidental Diagnosis in a Patient with Long-term Arthralgia. 
6. William Hofer (2003) Giant cell tumor: clinical presentation Giant cell tumor: clinical presentation. Medwave 3(11): e3280.

7. José Mario de la Garza N, Cosme A Ceccopieri, Humberto Cruz Ortiz, Luis R Díaz Rodríguez, Rogelio Martínez Macías (1999) Giant cell tumor of bone. General aspects of 11 cases. 62(4): 240-244.

8. Andrés Aguilar Ezquerra, Jorge López Subías, Marina Lillo Adán, Antonio Peguero Bona (2015) Treatment of Giant Cell Tumors. Revista Cubana de Ortopedia y Traumatología 29(1): 1-7.

9. M Debén Sánchez, D Ledesma Mateos (2004) Giant-Cell Tumour As a Cause of Chronic Pain in an Upper Extremity. 33(9): 522.

10. Oscar Aresa, Xavier Conesa, Roberto Seijas, Pedro Huguet, Rafae González, et al. (2010) Giant cell tumor of bone in a patient with HIV infection. 28(6): 396-397.

11. http://www.bvs.hn/RMH/pdf/1953/pdf/Vol21-1-1953-5.pdf

12. Jorge Llanos C, Cristián García B, Roberto Oyanedel Q, Eduardo Villanueva A, Johana Otero 0, et al. (2008) Plain radiological study in giant cell tumor (GCT) diagnosis among pediatric patients. Anatomoradiological correlation. Revista Chilena de Radiología 14(2): 62-67.

13. EG Estrada-Villaseñor, LM Linares-González, EA Delgado-Cedillo, R González-Guzmán, G Rico-Martínez (2015) Prevalence and Clinicopathological Characteristics of Giant Cell Tumors. 29(6).

14. Marcos A Rodríguez, Nicolás Casales, Claudio Silveri, Jaqueline Cardozo, Paola Filomeno, et al. (2017) Denosumab, alternative treatment in giant cell tumor of bone. Rev Méd Urug 33(2): 152-155.

15. h t t p : / / ve.s c i e lo.org / s c i e lo.p h p ? s c ript=s ci arttext\&pid=S0798-0582200700030001212

16. Herrera Pérez M, González Gaitano M, Vega Sanginés J, Coll Mesa L (2008) Giant cell tumor: an updated review from the treatment of a typical case. $5(15)$.

\section{ISSN: 2574-1241}

DOI: 10.26717/BJSTR.2021.33.005368

Alicia Tamayo Figueroa. Biomed J Sci \& Tech Res

CC $(-)$ This work is licensed under Creative

Submission Link: https://biomedres.us/submit-manuscript.php
17. D Luis Muscolo, Luis A Aponte Tinao, Miguel Calabrese, Miguel A Ayerza, Y Maximiliano Ranalletta. Giant cell tumor of the knee. Rev Asoc Arg Ortop y Traumatol 66(2): 174-178.

18. Enrique A Pancorbo Sandoval, Alberto Delgado Quiñones, Juan C Martín Tirado, José A Quesada Pérez, Ramón González Santos. Treatment of the giant cells tumor with curettage and graft of porous coral hydroxyapatite HAP-200®.

19. Pablo Arbeláez Echeverri, Jorge Manrique Succar, Francisco B Linares Restrepo (2017) Giant cell tumour of the bone in children and adolescents: Report of 11 cases. 31(4): 172-177.

20. Rafael Bracamonte-Barahona, Ingrid Calderón-Sauri, Judith ChanJiménez, Katia Flores-Mendoza, Ricardo Alejos-Gómez, et al. (2018) Giant cell tumor of ischiopubic location in a pediatric patient: clinical case report. 20(2): 93.97.

21. Luis Jair Sánchez-Torres, Abraham Flores Flores, Maricela Santos Hernández (2012) Giant cell tumor of bone in patients less than 20 years of age. 14(1): 26-30.

22. Luis Daniel Valladares-Vijil, Héctor Silva-Cárcamo, Roger ArmandoDominguez (2015) Giant Cell Tumor of Bone: Incidental Diagnosis in a Patient with Long-term Arthralgia.

23. JG Martínez-Estrada, O Santamaría-Bahena. Joint replacement and giant-cell tumor. Report of 8 cases. 30(5).

24. Elfego Bernabé Castañeda, Daniel López Torres, Oswaldo Guadalupe Ballinas Ordóñez, José Antonio Enríquez Castro, Jorge Luis Hernández López (2003) Tumor de células gigantes de altaagresividad en rodilla. Reporte de 4 casos 17(3): 145-152.

$\begin{array}{ll}\text { BIOMEDICAL } & \text { Assets of Publishing with us } \\ \text { RESEARCHES } & \text { - Global archiving of articles } \\ & \text { - Immediate, unrestricted online access } \\ & \text { - Rigorous Peer Review Process } \\ & \end{array}$

